\title{
Assessment of Melaleuca cajuputi as Heavy Metals Phytoremediator for Sewage Sludge Contaminated Soil
}

\author{
${ }^{1,3}$ Shibli Nik Mohd, ${ }^{2}$ Nik Muhamad Majid, \\ ${ }^{3}$ Noor Azhar Mohamed Shazili and ${ }^{1,2}$ Arifin Abdu \\ ${ }^{1}$ Department of Forest Management, Faculty of Forestry, \\ University Putra Malaysia, 43400 UPM Serdang, Selangor, Malaysia \\ ${ }^{2}$ Institute of Tropical Forestry and Forest Products (INTROP), \\ University Putra Malaysia, 43400 UPM Serdang, Selangor, Malaysia \\ ${ }^{3}$ Faculty of Science and Technology, University Malaysia Terengganu, \\ 21200, Kuala Terengganu, Malaysia
}

Received 2013-07-04, Revised 2013-08-15; Accepted 2013-08-21

\begin{abstract}
In 2011, total marine capture landings in Peninsular Malaysia decreased by $3.9 \%$ which amounted to $1,373,105$ tonnes as compared to $1,428,881$ tonnes in 2010 . The decline is connected to marine pollution which mainly comes from land based sources. Coastal forests play an important role affecting the marine ecosystem health and need to be conserved as a buffer to minimize pollution input into marine ecosystem. Heath forest, a type of coastal forest that receives less attention compared to mangroves, also has similar role. Melaleuca cajuputi that dominates heath forest has high potential as a phytoremediator of heavy metals and also has high economic values. A greenhouse experiment was conducted to evaluate the potential of this species to extract heavy metals namely $\mathrm{Zn}$ and $\mathrm{Cd}$ from soil. Four levels of treatment were prepared where the test media was mixed with different amounts of sewage sludge (v/v) namely; T1 (control-soil only), T2 (30\% sludge $+70 \%$ soil), T3 (50\% sludge $+50 \%$ soil) and T4 (70\% sludge $+30 \%$ soil). After 90 days of experimental period, the accumulation of $\mathrm{Zn}$ was found to be high in the roots $\left(137.19 \mathrm{mg} \mathrm{kg}^{-1}\right)$, followed by the leaves $\left(135.0 \mathrm{mg} \mathrm{kg}^{-1}\right)$ and stems $\left(102.24 \mathrm{mg} \mathrm{kg}^{-1}\right)$. As for $\mathrm{Cd}$ the highest concentration was in the roots $(2.05 \mathrm{mg}$ $\mathrm{kg}^{-1}$ ), stems (1.78 $\mathrm{mg} \mathrm{kg}^{-1}$ ) and leaves $\left(1.66 \mathrm{mg} \mathrm{kg}^{-1}\right)$. The species Transfer Factor (TF) values in the greenhouse experiment were $>1$ but the Bio-Concentration Factor $(\mathrm{BCF})$ values are $\leq 1$. This result shows that $M$. cajuputi is tolerant to $\mathrm{Zn}$ and $\mathrm{Cd}$ toxicity (low BCF) but able to transfer these elements (high TF) to the shoots for removal by leaf fall or by harvesting the shoots. In addition, the accumulation of $\mathrm{Zn}$ and $\mathrm{Cd}$ were high in the roots which suggests that $\mathrm{Zn}$ and $\mathrm{Cd}$ were efficiently immobilized (in the roots) from entering the marine ecosystem.
\end{abstract}

Keywords: Phytoremediation, Melaleuca cajuputi, Heavy Metals, Heathand Coastal Forests

\section{INTRODUCTION}

In 2011, the total marine capture landings in Peninsula Malaysia decreased by $3.9 \%$ which amounted to $1,373,105$ tonnes as compared with $1,428,881$ tonnes in 2010 (DOF, 2011). One of the reasons of declining marine capture landing might be due to pollution of the marine ecosystem. Biological effects from marine pollution result in economic effects (Ofiara and Seneca, 2006). There are different pathways by which contaminants can be introduced into the marine environment: direct input, riverine contribution and drawdown from the atmosphere (Kroger et al., 2002). Most sources of marine pollution are land based such as

Corresponding Author: Arifin Abdu, Department of Forest Management, Faculty of Forestry, Universiti Putra Malaysia, 43400 UPM Serdang, Selangor, Malaysia Tel: +603-89467177 Fax: +603-89432514 
agricultural run-off, industrial discharges and substances released from sewage treatment plants.

Coastal forests play an important role in marine ecosystem health and need to be conserved with a new perspective not only as mitigation from natural hazards such as tsunami and hurricane but as a buffer to minimize pollution input into the marine ecosystem. Zhang et al. (2010) stated that mangroves wetland especially with Sonneratiaapelata species has great potential in removing heavy metals and nutrients in coastal areas. Mangrove tree is a biochemical reactor that plays an important role in the physiological and biochemical processes including organic matter decomposition (Ramos-e-Silva et al., 2006).

Heath forest or Melaleuca forest, a type of coastal forest that receives less attention compared to mangroves, also has an important role in regulating pollution input into the marine ecosystem. According to Okubo et al. (2003) Melaleuca forest thrive son BRIS soils that are rich with pyrite and contain peat layer underneath the sandy soil. The decline of Melaleuca forest could pose pollution risk to the marine environment as the pyrites and peat layer would cause acid drainage with high heavy metal loads that is toxic to marine life. Cabon et al. (2010) found out that most of the metallic elements were released from the sediments into the seawater during the first fifteen minutes of acid exposure after which a high degree of pollution was induced if acids leached into seawater were not rapidly diluted.

The importance of conserving coastal forests has been recognized in numerous scientific literatures but knowledge on how wetland plants interact with pollution was incomplete (Stottmeister et al., 2003). Phytoremediation is a soil remediation technique using plants and also provide an effective way to control pollution from spreading (Majid et al., 2011; 2012a; 2012b). This technique utilizes plant's ability to extract pollutants, transform pollutants into nontoxic compounds or degrade pollutants utilizing only solar energy (Alkorta et al., 2004). Thus, the objective of this study was to assess the tolerance and accumulation of heavy metals namely $\mathrm{Zn}$ and $\mathrm{Cd}$ by $M$. cajuputi and to evaluate the potential of the species in extracting heavy metals from the soil.

\section{MATERIALS AND METHODS}

\subsection{Experimental Design and Data Collection}

The study was conducted in a complete random design experiment in the greenhouse. The contaminated test media were prepared by mixing (v/v) dewatered sewage sludge with normal garden soil. Each treatment pot was filled up to about $16 \mathrm{~kg}$ of test media. Four levels of treatment were prepared namely; T1 (controlsoil only), T2 (30\% sludge $+70 \%$ soil), T3 (50\% sludge $+50 \%$ soil) and T4 (70\% sludge $+30 \%$ soil). The study was conducted for 90 days before the plants were harvested for laboratory analysis. No fertilizer was applied throughout the experiment as it was assumed that the treatment media would adequately supply the required nutrients for optimum growth. Growth of the $M$. cajuputi saplings was measured by the height and stem basal diameter taken every two weeks.

Plant samples were washed thoroughly with distilled water and dried in an oven at $60^{\circ} \mathrm{C}$ for two days whereas soil samples of the treatment media were air dried for about three days prior to laboratory analysis. Samples of treatment media were analyzed for $\mathrm{pH}$, Cation Exchange Capacity (CEC), total carbon, total nitrogen and heavy metals namely $\mathrm{Zn}, \mathrm{Cu}$ and $\mathrm{Cd}$. Determination of media $\mathrm{pH}$ were measured with a $\mathrm{pH}$-meter in water supernatant obtained from mixing the soil with distilled water in 1:5 ratios (w/v) for $15 \mathrm{~min}$. Total carbon and nitrogen were determined by automated CHNS analyzer. CEC was determined by neutral ammonium acetate leaching as used by the United States Department of AgricultureNational Resources and Conservation Services (USDANRCS) Soil Survey Staff standard methods for soil analysis (Burt, 2004). Soil and plant heavy metal concentrations were extracted by wet digestion method with aqua-regia solution (Allen et al., 1974).

Heavy metals in the extraction solution were then determined with Atomic Absorption Spectrophotometer (AAS). Recovery tests for heavy metals extraction reliability was conducted using Standard reference material (SRM) certified materials for plant sample (material code 1573A; tomato leaves) and soil (material code HISS-1; marine sediment) obtained from United States National Institute of Standard and Technology (NIST) and over 90\% recovery was obtained and maintained.

\subsection{Statistical Analysis and Phytoremediation Potential Assessment}

All data were subjected to Duncan's Multiple Range Test (DMRT) to detect and rank significant differences between treatments and groups. Assessing the potential of a plant species in phytoremediation was achieved by applying the Bio-Concentration Factor (BCF) and Translocation Factor (TF). Bio-Concentration Factor $(\mathrm{BCF})$ is a concentration ratio of heavy metal concentration in plant tissues over concentration in soil (Liang et al., 2009). Values $>1$ indicate heavy metals are 
accumulated in the biological tissues. On the other hand, Translocation factor (TF) is the ratio of concentration in plant shoots over the concentration in the roots (Colle et al., 2009). Values $>1$ indicate that the species transfer or translocate heavy metals from roots to shoots or heavy metals are highly mobile in the species (Justin et al., 2011; Majid et al., 2012c; Sundarajoo et al., 2013).

\section{RESULTS AND DISCUSSION}

\subsection{Chemical Properties of the Treatment Media}

Table 1 shows selected chemical properties of the treatment media. The control media without sewage sludge added was acidic with $\mathrm{pH}$ of 4.94 but when sewage sludge was added to the subsequent treatments the $\mathrm{pH}$ increased to 5.63 in treatment T4. Similarly, the CEC in T1 was very low $\left(3.0 \mathrm{cmol} \mathrm{kg}{ }^{-1}\right)$ but increased significantly $(41.83 \mathrm{cmol}$ $\mathrm{kg}^{-1}$ ) in T4. Total carbon also increased from 0.5 to $3.1 \%$ whereas total nitrogen from $0.1 \%$ in $\mathrm{T} 1$ to $0.5 \%$ in $\mathrm{T} 4$. The significant difference among the treatment levels was due to high organic materials in the sludge (Amuda et al., 2008) but the differences depends on the age and the origin of the sewage sludge (Soler-Rovira et al., 1996) where in this experiment the differences of nitrogen and carbon were not very large.

The concentrations of $\mathrm{Zn}$ and $\mathrm{Cd}$ in the treatment media increased significantly with increased amount of sewage sludge. The control or $\mathrm{T} 1$ treatment has $\mathrm{Zn}$ at $26.67 \mathrm{mg} \mathrm{kg}^{-1}$ and $\mathrm{Cd}$ at $0.22 \mathrm{mg} \mathrm{kg}^{-1}$. The concentrations then increased to $131.01 \mathrm{mg} \mathrm{kg}^{-1}$ and $10.36 \mathrm{mg} \mathrm{kg}^{-1}$ respectively in T4 treatment. According to Alidadi et al. (2007) organic materials in the sewage sludge contribute to the increased $\mathrm{pH}$ and $\mathrm{CEC}$ values. This is the reason why sewage sludge is often used as soil amendment to neutralize acid soils (Hani et al., 1996; Bramryd, 2002). However, sewage sludge is the contributor to the heavy metal contamination in agricultural soil (Merrington et al., 2003; Paramasivam et al., 2006) and this can be seen in the treatment media with 50 and $70 \%$ sewage sludge mix (T3 and T4) where $\mathrm{Zn}$ and $\mathrm{Cd}$ concentrations in these treatments exceeded the normal level of uncontaminated soil in Malaysia of $92.0 \mathrm{mg} \mathrm{kg}^{-1}$ of $\mathrm{Zn}$ and $0.032 \mathrm{mg} \mathrm{kg}^{-1}$ of Cd (Zarcinas et al., 2004).

\subsection{Distribution of $\mathrm{Zn}$ and $\mathrm{Cd}$ in Different Plant Parts}

Figure 1 show the concentration of $\mathrm{Zn}$ and $\mathrm{Cd}$ in the roots, stems and leaves of $M$. cajuputi after 90 days. The concentration of $\mathrm{Zn}$ ranged from $230-320 \mathrm{mg} \mathrm{kg}^{-1}$ but there were no significant difference $(\mathrm{p} \leq 0.05)$ among the treatments with sewage sludge except for the control (80 $\left.\mathrm{mg} \mathrm{kg}^{-1}\right)$. However, $\mathrm{Cd}$ concentration was not significantly different $(\mathrm{p} \leq 0.05)$, ranging from 2.05-5.29 $\mathrm{mg} \mathrm{kg}^{-1}$ in all treatments except for treatment $\mathrm{T} 3$ which was the lowest (less than $2.9 \mathrm{mg} \mathrm{kg}^{-1}$ ).

The non-significant different in the plant $\mathrm{Zn}$ and $\mathrm{Cd}$ concentration between the treatments indicate $\mathrm{Zn}$ and $\mathrm{Cd}$ were efficiently regulated by the species irrespective of the concentrations in the treatments as uptake of both element was actively transferred across the cell wall by specific carrier proteins (Kramer et al., 2007; Mejare and Bulow, 2001). This also shows that $M$. cajuputi is very tolerant to $\mathrm{Zn}$ and $\mathrm{Cd}$ contamination.

The distribution of $\mathrm{Zn}$ and $\mathrm{Cd}$ in the different plant parts were generally high in the roots ranging from 111.03-137.19 and 0.74-2.05 $\mathrm{mg} \mathrm{kg}^{-1}$, respectively. This shows that $M$. cajuputi is an efficient excluder species that manage to retain high levels of heavy metals in the roots. However, some $\mathrm{Zn}$ was transferred to the leaves (81.44-135 mg kg-1) and a small amount accumulated in the stems (43.11-102.24 mg kg-1). Cd has been found to have accumulated in the stems $\left(0.23-1.78 \mathrm{mg} \mathrm{kg}^{-1}\right)$ more than the leaves $\left(0.49-1.66 \mathrm{mg} \mathrm{kg}^{-1}\right)$. Accumulation of $\mathrm{Zn}$ in the leaves was due to its importance in biochemical reaction in photosynthesis, whereas $\mathrm{Cd}$ which is nonessential and toxic was transformed and stored in the stems and finally expelled as $M$. cajuputi frequently shed its papery bark.

\subsection{Evaluation of M. Cajuputi as Phytoremediator Species}

Table 2 shows the Bio-Concentration Factor (BCF) and Translocation Factor (TF) as an evaluation of phytoremediation potential of $M$. cajuputi. The value of $\mathrm{BCF}$ was high in the control treatment for $\mathrm{Zn}$ (1.3) and $\mathrm{Cd}$ (7.4). However, in other treatments, the BCF values were $<1$ indicating that $M$. cajuputi is not an accumulator species. On the other hand, TF values of $M$. cajuputi in every treatments (except $\mathrm{T} 3$ for $\mathrm{Cd}$ ) show values $>1$, indicating that $\mathrm{Zn}$ and $\mathrm{Cd}$ were efficiently transferred to the shoots. This might be due to the high transpiration rate of the species which is common for salt tolerant plants (Nguyen et al., 2009; Cramer et al., 1999).

In general, plants that have BCF and TF values of $>1$ are sought for heavy metal extraction (Alkorta et al., 2004). Results from this experiment however, shows low BCF but high TF. 
Table 1. Selected chemical properties of the treatment media before planting

\begin{tabular}{lllllrr}
\hline Treatment & $\mathrm{pH}$ & $\begin{array}{l}\text { CEC } \\
(\mathrm{cmol} / \mathrm{kg})\end{array}$ & $\begin{array}{l}\text { TC } \\
(\%)\end{array}$ & $\begin{array}{l}\text { TN } \\
(\%)\end{array}$ & $\begin{array}{l}\text { Zn } \\
(\mathrm{mg} / \mathrm{kg})\end{array}$ & $\begin{array}{r}\mathrm{Cd} \\
(\mathrm{mg} / \mathrm{kg})\end{array}$ \\
\hline T1 (Control) & $4.94^{\mathrm{c}}$ & $3.00^{\mathrm{c}}$ & $0.5^{\mathrm{c}}$ & $0.1^{\mathrm{c}}$ & $26.67^{\mathrm{d}}$ & $0.22^{\mathrm{c}}$ \\
T2(30\% SS) & $4.78^{\mathrm{c}}$ & $8.01^{\mathrm{bc}}$ & $2.6^{\mathrm{b}}$ & $0.4^{\mathrm{b}}$ & $79.74^{\mathrm{c}}$ & $2.60^{\mathrm{b}}$ \\
T3 (50\% SS) & $5.12^{\mathrm{b}}$ & $12.07^{\mathrm{b}}$ & $3.0^{\mathrm{a}}$ & $0.4^{\mathrm{b}}$ & $102.96^{\mathrm{b}}$ & $10.07^{\mathrm{a}}$ \\
T4 (70\% SS) & $5.63^{\mathrm{a}}$ & $41.83^{\mathrm{a}}$ & $3.1^{\mathrm{a}}$ & $0.5^{\mathrm{a}}$ & $131.01^{\mathrm{a}}$ & $10.36^{\mathrm{a}}$ \\
\hline
\end{tabular}

Note: Averages within columns followed by different letters indicate statistically difference $(\mathrm{p} \leq 0.05)$ with Duncan's Test; SS $=$ Sewage Sludge

Table 2. BCF and TF for M. cajuputi in the greenhouse experiment for each treatment

\begin{tabular}{llll}
\hline & Treatment & Zn & Cd \\
\hline BCF & T1 & 07.4 \\
& T2 & 1.3 & 00.4 \\
& T3 & 0.8 & 00.1 \\
TF & T4 & 0.3 & 00.2 \\
& T1 & 0.4 & 02.7 \\
& T2 & 4.6 & 01.1 \\
& T3 & 3.1 & 00.2 \\
& T4 & 2.0 & 11.1 \\
\hline
\end{tabular}
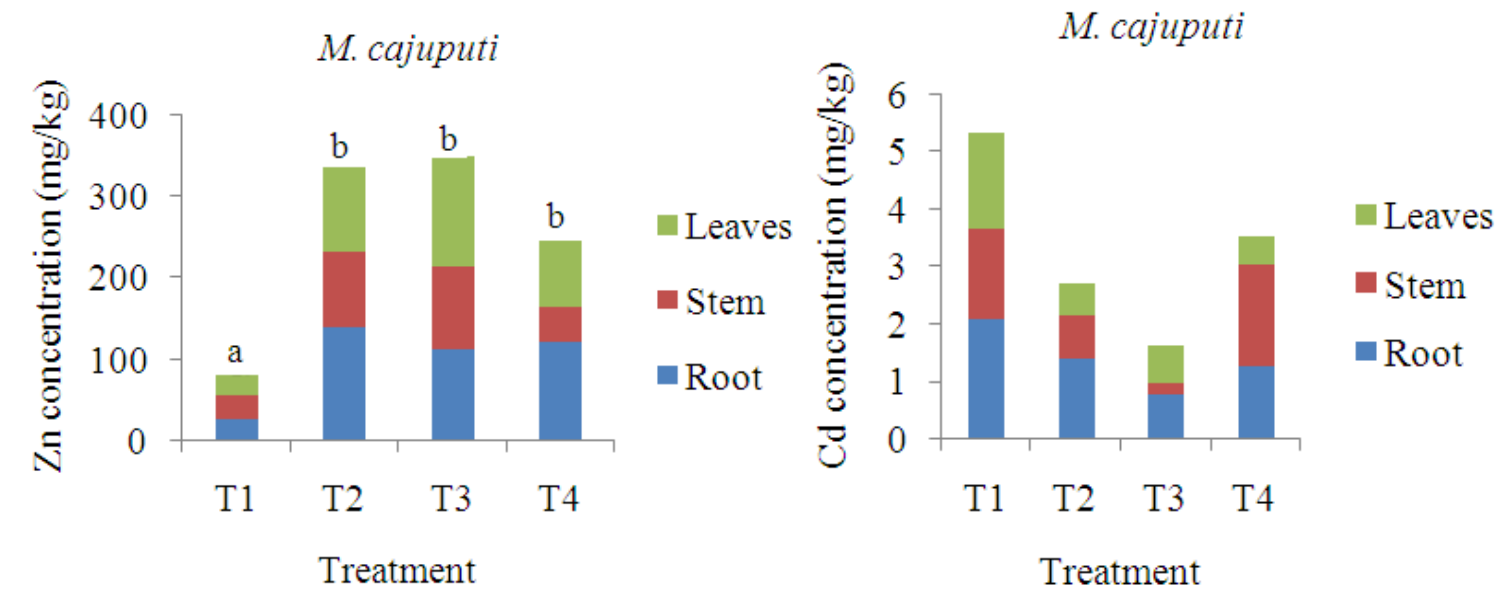

Fig. 1. Concentrations of $\mathrm{Zn}$ and $\mathrm{Cd}$ in different plant parts of M. cajuputi

This means that $M$. cajuputi is not $\mathrm{Zn}$ and $\mathrm{Cd}$ hyperaccumulator species but with high biomass of $M$. cajuputi that is commonly observed in the natural coastal forests, its ability to store $\mathrm{Cd}$ in the stems and high transpiration rate indicate that this species has high potential as a phytoremediator. This also shows how $M$. cajuputi coastal forests function as a buffer zone to control land based pollution especially heavy metals from entering the marine environment.

\section{CONCLUSION}

M. cajuputi has high potential as a phytoremediator and also has high economic value. M. cajuputi coastal forests provide a natural buffering ability to minimize heavy metal pollution from entering the marine environment. Conservation of this coastal forest which is dominant in the east coast of Peninsula Malaysia is highly desired to support the limited distribution of mangrove areas in similar location apart from the potential of the species for commercial use.

\section{ACKNOWLEDGEMENT}

The researchers would like to acknowledge the financial support from the Ministry of Higher education of Malaysia through Fundamental Research Grant Scheme (FRGS) and Research University Grant Scheme (RUGS). 


\section{REFERENCES}

Alidadi, H., A.A. Najafpoor and A. Parvesh, 2007. Determination of carbon/nitrogen ratio and heavy metals in bulking agents used for sewage sludge composting. Pakistan J. Biol. Sci., 10: 4180-4182. DOI: $10.3923 /$ pjbs.2007.4180.4182

Alkorta, I., J. Hernandez-Allica, J.M. Becerril, I. Amezaga and I. Albizu et al., 2004. Recent findings on the phytoremediation of soils contaminated with environmentally toxic heavy metals and metalloids such as zinc, cadmium, lead and arsenic. Rev. Environ. Sci., Biotechnol., 71-90. DOI: 10.1023/B:RESB.0000040059.70899.3d

Allen, S.E., H. Grimshaw, J.A. Parkinson and C. Quarmby, 1974. Chemical Analysis of Ecological Material. 1st Edn., Blackwell Scientific Publications. Oxford, ISBN-10: 0632003219, pp: 565.

Amuda, O.S., A.A. Deng, O. Alade and Y.T. Hung. 2008. Conversion of Sewage Sludge to Biosolids. In: Handbook of Environmental Engineering, Volume 7: Biosolids Engineering and Management, Wang, L.K., N.K. Shammas and Y.T. Hung (Eds.), Humana Press, New Jersey, ISBN-10: 1588298612, pp: 65-115.

Bramryd, T., 2002. Impact of sewage sludge application on the long term nutrient balance in acid soils of Scots Pine (Pinussylvestris, L.) forests. Water Air Soil Pollut., 140: 381-399. DOI: 10.1023/A:1020142311652

Burt, R., 2004. Soil survey laboratory methods manual. USDA-NRCS.

Cabon, J., P. Giamarchi and S.L. Floch, 2010. A study of marine pollution caused by the release of metals into seawater following acid spills. Marine Pollut. Bull., 60: 998-1004. DOI: 10.1016/j.marpolbul.2010.02.002

Colle, C., C. Madoz-Escande and E. Leclerc, 2009. Foliar transfer into the biosphere: Review of translocation factors to cereal grains. J. Environ. Radioactivity, 100: 683-689. DOI: 10.1016/j.jenvrad.2008.10.002

Cramer, V.A., P.J. Thorburn and G.W. Fraser, 1999. Transpiration and groundwater uptake from farm forest plots of Casuarinaglauca and Eucalyptus camaldulensis in saline areas of Southeast Queensland, Australia. Agric. Water Manage., 39: 187-204. DOI: 10.1016/S0378-3774(98)00078-X
DOF, 2011. Annual Fisheries Statistics. Department of Fisheries, Malaysia.

Hani, H., A. Siegenthaler and T. Candinas, 1996. Soil effects due to sewage sludge application in agriculture. Fertilizer Res., 43: 149-156. DOI: 10.1007/BF00747695

Justin, V., N.M. Majid, M.M. Islam and A. Abdu, 2011. Assessment of heavy metal uptake and translocation in Acacia mangium for phytoremediation of cadmium-contaminated soil. J. Food Agric. Environ., 9: 588-592.

Kramer, U., I.N. Talke and M. Hanikenne, 2007. Transition metal transport. FEBS Lett., 581: 22632272. DOI: $10.1016 /$ j.febslet.2007.04.010

Kroger, S., S. Piletskyand and A.P.F. Turner, 2002. Biosensors for marine pollution research, monitoring and control. Marine Pollut. Bull., 45: 2434. DOI: 10.1016/S0025-326X(01)00309-5

Liang, H., T. Lin, J. Chiou and K. Yeh, 2009. Model evaluation of the phytoextraction potential of heavy metal hyperaccumulators and nonhyperaccumulators. Environ. Pollut., 157: 19451952. DOI: 10.1016/j.envpol.2008.11.052

Majid, N.M., M.M. Islam, M.E. Nap, M. Ghafoori and A. Abdu, 2012c. Heavy metal uptake and translocation by Justicia gendarussa Burm F. from textile sludge contaminated soil. Acta Agric. Scandinavica Section B: Soil Plant Sci., 62: 101108. DOI: 10.1080/09064710.2011.579994

Majid, N.M., M.M. Islam, R. Abdul-Rauf, P. Ahmadpour and A. Abdu, 2012a. Assessment of heavy metal uptake and translocation in Dyera costulata for phytoremediation of cadmium contaminated soil. Acta Agric. Scandinavica Section B: Soil Plant Sci., 62: 245-250. DOI: 10.1080/09064710.2011.603740

Majid, N.M., M.M. Islam, V. Justin, A. Abdu and P. Ahmadpour, 2011. Evaluation of heavy metal uptake and translocation by Acacia mangium as a phytoremediator of copper contaminated soil. Afr. J. Biotechnol., 10: 8373-8379.

Majid, N.M., M.M. Islam, Y. Riasmi and A. Abdu, 2012b. Assessment of heavy metal uptake and translocation by Pluchea indica $\mathrm{L}$. from sawdust sludge contaminated soil. J. Food, Agric. Environ., 10: 849-855.

Mejare, M. and L. Bulow, 2001. Metal-binding proteins and peptides in bioremediation and phytoremediation of heavy metals. Trends Biotechnol., 19: 67-73. DOI: 10.1016/S0167-7799(00)01534-1 
Merrington, G., I. Oliver, R.J. Smernik and M.J. McLaughlin, 2003. The influence of sewage sludge properties on sludge-borne metal availability. Adv. Environ. Res., 8: 21-36. DOI: 10.1016/S10930191(02)00139-9

Nguyen, T.N., H. Saneoka, R. Suwa and K. Fujita, 2009. Provenance variation in tolerance of Melaleuca cajuputi trees to interactive effects of aluminum and salt. Trees, 23: 649-664. DOI: 10.1007/s00468-0080309-5

Ofiara, D.D. and J.J. Seneca, 2006. Biological effects and subsequent economic effects and losses from marine pollution and degradations in marine environments: Implications from the literature. Marine Pollut. Bull., 52: 844-864. DOI: 10.1016/j.marpolbul.2006.02.022

Okubo, S., K. Takeuchi, B. Chakranon and A. Jongskul, 2003. Land characteristics and plant resources in relation to agricultural land-use planning in a humid tropical strand plain, southeastern Thailand. Landscape Urban Plann., 65: 133-148. DOI: 10.1016/S0169-2046(03)00011-2

Paramasivam, S., K.S. Sajwan and K. Alva, 2006. Incinerated sewage sludge products as amendments for agricultural soils: Leaching and plant uptake of trace elements. Water Air Soil Pollut., 171: 273-290. DOI: $10.1007 / \mathrm{s} 11270-005-9042-5$
Ramos-e-Silva, C.A., A.P. da Silva and S.R. de Oliveira, 2006. Concentration, stock and transport rate of heavy metals in a tropical red mangrove, Natal, Brazil. Marine Chem., 99: 2-11. DOI: 10.1016/j.marchem.2005.09.010

Soler-Rovira, E., J. Soler-Soler, J. Soler-Rovira and A. Polo, 1996. Agricultural use of sewage sludge and its regulation. Fertilizer Res., 43: 173-177. DOI: 10.1007/BF00747698

Stottmeister, U., A. Wiebner, P. Kuschk, U. Kappelmeyer and M. Kastner et al., 2003. Effects of plants and microorganisms in constructed wetlands for wastewater treatment. Biotechnol. Adv., 22: 93117. DOI: 10.1016/j.biotechadv.2003.08.010

Sundarajoo, K., A. Abdu, D.S. Karam, H. Abdul-Hamid and S. Jusop et al., 2013. Heavy metal uptake and translocation by Dipterocarpus verrucosus from sewage sludge contaminated soil. Am. J. Environ. Sci., 9: 259-268. DOI: 10.3844/ajessp.2013.259.268

Zarcinas, B.A., I. CheFauziah, M.J. McLaughlin and G. Cozens, 2004. Heavy metals in soils and crops in Southeast Asia. 1. Peninsular Malaysia. Environ. Geochem. Health, 26: 343-357. DOI: 10.1007/s10653-005-4669-0

Zhang, J.E., J. Liu, Y. Ouyang, B. Liao and B. Zhao, 2010. Removal of nutrients and heavy metals from wastewater with mangrove Sonneratiaapetala BuchHam. Ecol. Eng., 36: 807-812. DOI: 10.1016/j.ecoleng.2010.02.008 